\title{
Article \\ Flood and Renewable Energy Humanitarian Engineering Research: Lessons from Aggitis, Greece and Dhuskun, Nepal
}

\author{
Spyros Schismenos ${ }^{1,2, *}{ }^{\circledR}$, Garry J. Stevens ${ }^{1}{ }^{\mathbb{D}}$, Nichole Georgeou ${ }^{1}$, Dimitrios Emmanouloudis ${ }^{2,3}$, \\ Surendra Shrestha ${ }^{4}\left(\mathbb{D}\right.$, Biraj S. Thapa ${ }^{5}$ and Supriya Gurung ${ }^{1}$ \\ 1 School of Social Sciences, Humanitarian and Development Research Initiative (HADRI), \\ Western Sydney University, Sydney 2747, Australia; g.stevens@westernsydney.edu.au (G.J.S.); \\ n.georgeou@westernsydney.edu.au (N.G.); supriya.gurung@naturalhazards.com.au (S.G.) \\ 2 UNESCO Chair on Conservation and Ecotourism of Riparian and Deltaic Ecosystems, \\ International Hellenic University, 66100 Drama, Greece; demmano@teiemt.gr \\ 3 Department of Forestry and Natural Environment, International Hellenic University, 66100 Drama, Greece \\ 4 School of Engineering, Western Sydney University, Sydney 2747, Australia; s.shrestha@westernsydney.edu.au \\ 5 Department of Mechanical Engineering, Green Hydrogen Lab, Kathmandu University, \\ Dhulikhel 45200, Nepal; bst@ku.edu.np \\ * Correspondence: s.schismenos@westernsydney.edu.au
}

check for updates

Citation: Schismenos, S.; Stevens,

G.J.; Georgeou, N.; Emmanouloudis,

D.; Shrestha, S.; Thapa, B.S.; Gurung,

S. Flood and Renewable Energy

Humanitarian Engineering Research:

Lessons from Aggitis, Greece and

Dhuskun, Nepal. Geosciences 2022, 12,

71. https://doi.org/10.3390/

geosciences12020071

Academic Editors: Pedro Pinto

Santos and Jesus Martinez-Frias

Received: 7 December 2021

Accepted: 1 February 2022

Published: 3 February 2022

Publisher's Note: MDPI stays neutral with regard to jurisdictional claims in published maps and institutional affiliations.

Copyright: (C) 2022 by the authors. Licensee MDPI, Basel, Switzerland. This article is an open access article distributed under the terms and conditions of the Creative Commons Attribution (CC BY) license (https:// creativecommons.org/licenses/by/ $4.0 /)$.

\begin{abstract}
Climate and energy crises are increasing worldwide. Community-led humanitarian engineering interventions for localized sustainable development and disaster resilience could support populations at risk. This article presents findings from a study that investigated flood response and energy needs of two riparian communities in Greece and Nepal. The findings indicate that the codevelopment of a hybrid unit for hydropower generation and flood warning is most preferred. This prototype could find applications in different riparian areas as either a main or supplementary system.
\end{abstract}

Keywords: renewable energy; flood hazard; early warning; prototype development; remote research

\section{Introduction}

Floods and storms are the most frequent natural hazards worldwide and pose a serious threat in many countries [1]. In October 2021, flash flooding and landslides caused by heavy late monsoon rain in Nepal and India resulted in more than 180 fatalities and major damage to homes, public infrastructure, and farms [2]. In the same month, a similar disaster also struck Greece. Heavy rainfall caused floods and mudslides in many parts of the country, with Evia, an island that was significantly damaged by wildfires in August, being the most impacted [3]. While the exposure to climate crises may be similar in many countries, low-income countries are disproportionally affected as they have fewer resources needed for disaster resilience [1], such as reliable energy and hazard response infrastructure. The transition to renewable energy sources, including off-grid systems, seems a pragmatic way to deal with both energy and climate threats [4]. However, this is not an easy task, particularly at the local level, where riparian communities often face the dual dilemma of energy and flood resilience insufficiency.

Large-scale systems for disaster management and energy generation tend to fail at smaller scales. Generalized early warning systems that focus on large basins cannot detect flash floods and other localized water hazards [5]. Small, off-grid communities in remote locations do not receive the benefits of main power networks or large renewable energy plants, a factor contributing to development constraints and poverty. While the construction of additional renewable energy stations to satisfy more populations sounds promising, this may come with substantial social and ecosystemic costs. For example, the excessive and unchecked building of larger-scale hydropower plants on the steep slopes of Nepal has affected local environmental conditions and intensified some flood and landslide phenomena [6]. 
Increasingly, small, community-based renewable energy systems are being used to support the daily power needs of off-grid communities, augment those with unstable mains access, and are proving reliable during extreme weather events [7]. One such example is Bihar, one of the poorest states in eastern India, which has limited mains energy infrastructure but where many of its districts are transitioning to off-gird renewables, such as solar energy. In August 2017, the state experienced extreme floods that affected more than 12 million people. Among the impacted areas, Araria, a rural village that runs on solar panels was under one meter of water but able to provide continuous power to thousands of people as the panels kept operating, unlike other emergency energy sources (diesel generators) that were damaged by the floods [8]. In Hackbridge, United Kingdom, solar panel operation during floods powers buildings in flood zones and supports "in-place" sheltering when evacuation is not possible [9]. In Hoboken, New Jersey, small-scale energy grids support early warning of coastal floods and alert local residents when the waters reach critical levels $[9,10]$. These examples highlight that localized renewables can support flood emergency management as a primary source for off-grid communities and as critical augmentation in higher-income countries.

Humanitarian engineering could be the key to re-thinking energy self-sufficiency and disaster resilience at the local level. This approach involves applications of both urgent and longer-term engineering solutions that center on community needs and consider the social, cultural, and environmental characteristics inherent to local requirements and capabilities [11,12]. A major difference with other engineering practices is that it proactively seeks the co-development of solutions with end-user populations using appropriate technologies, "traditional" knowledge, and local views [13]. When directed to prototype development, it can support the creation of sustainable, community-focused interventions that accord with the principles of both the United Nations 2030 Agenda for Sustainable Development and Sendai Framework for Disaster Risk Reduction. However, a major risk in humanitarian engineering research relates to the level of genuine trust and understanding developed between local stakeholders and (often) output-focused professionals. Lack of local engagement in all phases, power inequities and resistance to learning and adapting may undermine solutions and ultimately result in program failures [14,15].

While the literature showcases many community-based projects in renewable energy and early warning, there is little information regarding the development of combined and hybrid systems which integrate these key functions or community perceptions of the feasibility of such options [5,16]. Our study focus aligns with humanitarian engineering principles and prioritizes local stakeholders' views as essential elements for developing sustainable solutions. This article presents findings from our cross-country analysis of off-grid renewable energy generation and flood early warning needs in riparian communities, specifically their appraisals regarding (i) market available stand-alone systems (early warning systems, renewable energy generators), (ii) combined systems, and (iii) a conceptual hybrid prototype. To better understand common and context-specific needs and acceptable solutions, we compared two riparian communities-an on-grid, peri-urban village in a high-income country (Aggitis, Greece) and a remote, off-grid village in a lowincome country (Dhuskun, Nepal). While these communities present differences (e.g., infrastructure, socio-culture), they share similar threats and experiences, such as power outages during/after weather hazards. The findings of this study may not only support the engaged communities with practical solutions based on their capacity, but also draw lessons for other riparian communities with flood resilience and energy issues (e.g., in urban areas).

\section{Materials and Methods}

\subsection{Methods Selection}

The principal method was a semi-structured interview conducted over two rounds using the Delphi method. Round One took place from 23 April 2021 to 14 May 2021; Round Two from 19 to 25 July 2021. Interviews were conducted remotely as an appropriate approach to 
engage with international study participants under pandemic conditions. To support asset appraisal, the structure of Round Two was augmented with two decision-making frameworks; choice-based conjoint analysis (CBCA) and strengths, challenges, opportunities, responses, effectiveness (SCORE) analysis. Thematic analysis was used to analyze the interview data. Key elements of the study design are presented in Figure 1 and detailed below. A more detailed description of the study method is available at Schismenos et al. (2021) [17].

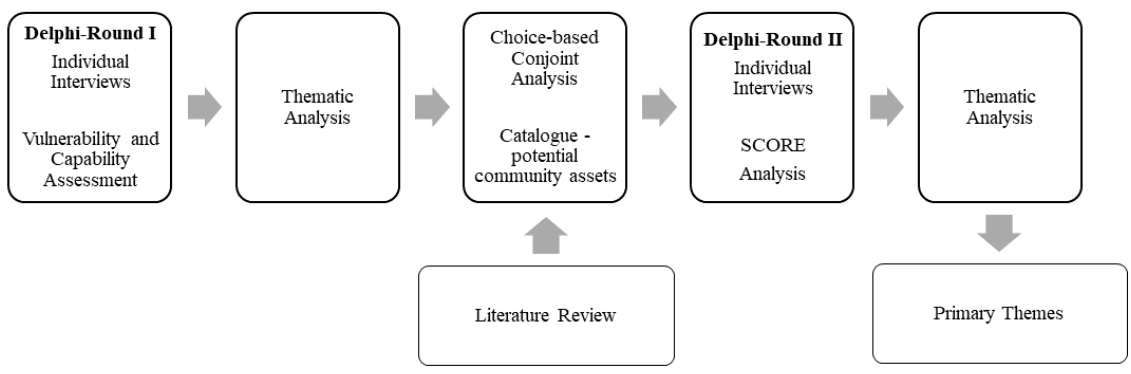

Figure 1. Study components and process.

\subsubsection{Delphi Method}

The Delphi method is a common decision-support technique in vulnerability and capability analysis [18], and prototype development research [19]. It draws on the informed views of those familiar with a topic area or resource, allows equal access and participant contribution, does not require face-to-face interaction and, through an iterative process, leads to "close to expert consensus" regarding a solution or application over a series of rounds [20]. This approach was appropriate to address the study's focal areas over two rounds. Round One examined perceptions of major hazard types affecting the community, related vulnerabilities and needs, and capabilities that could support their management. Round Two sought participant perceptions of appropriate solutions to address the priority needs identified in Round One. This employed a catalogue of community assets developed using Round One feedback and was additionally informed by a scoping review [16], and a literature review [15] of available options.

\subsubsection{Remote Research}

Remote research involves any research enquiry where the researcher and participants are not in the same physical space (in person) [21]. Our data collection was conducted digitally (via emails, phones, and videoconferencing) to ensure participant safety during the pandemic. Participant perceptions of the remote research process were assessed to determine potential impacts on access or expression of views and its acceptability for future research in this field.

\subsubsection{Semi-Structured Interviews and Validation}

Semi-structured interviews are a common method of data collection in qualitative research as they allow deep exploration of a topic, particularly areas where little data is available [22]. An orientation module and question set were developed for each round based on the study's research questions and tested in pilot interviews. Round Two questions were also based on the Round One responses. The final interview schedule (available as supplementary information-Tables S1 and S2) was validated with non-participating local residents and professionals, and a psychometrician to ensure clarity of meaning and content understanding $[23,24]$. All interviews were conducted in local languages (Greek, Nepali) to allow participants to most easily express their views [25]. The principal researcher (first author) conducted the Greek interviews and was assisted by a Nepalese interpreter (in-situ) for the Dhuskun interviews. 


\subsubsection{Choice-Based Conjoint Analysis}

Choice-based conjoint analysis is widely used in social, health, energy, and prototype development research [26-29]. It provides an understanding of how participants perceive the value of products, services, and options based on a comparison of their functions and features (attributes). The attributes are usually limited in number and presented in a catalogue format or a table [28,29]. The catalogue used in Round Two presents six options which were derived from a combination of a review of market-available options for such sites and participants' preferences for energy and flood hazard types from the Round One interview. This decision-support framework is appropriate for cross-community and cross-country analysis $[29,30]$. Figure 2 presents the catalogue of community assets participants reviewed in local languages during the Round Two interviews and which canvassed these options:

(1) Option 1. Small-scale hydropower system (Option and attributes based on SMART HYDRO, https:/ / www.smart-hydro.de/ assessed on: 10 November 2021)

(2) Option 2. Set of solar panels (Option and attributes based on GPM-250 W, Zhejiang G New Energy Technology Co., Zhejiang Province, China)

(3) Option 3. Flood siren system (Option and attributes based on Telegrafia flood siren system, https:/ /www.telegrafia.eu/en/solution/mass-public-warning/flood-warningsystem/ accessed on: 10 November 2021)

(4) Option 4. Flood alert SMS/email system (Option and attributes based on LEVELINEEWS, https:/ / www.aquaread.com/products/water-level/leveline-ews accessed on: 10 November 2021)

(5) Option 5. Combination of a set of solar panels and SMS/email flood alert system (Options 2 and 4)

(6) Option 6. Hybrid system-hydropower and flood siren (Options 1 and 3)

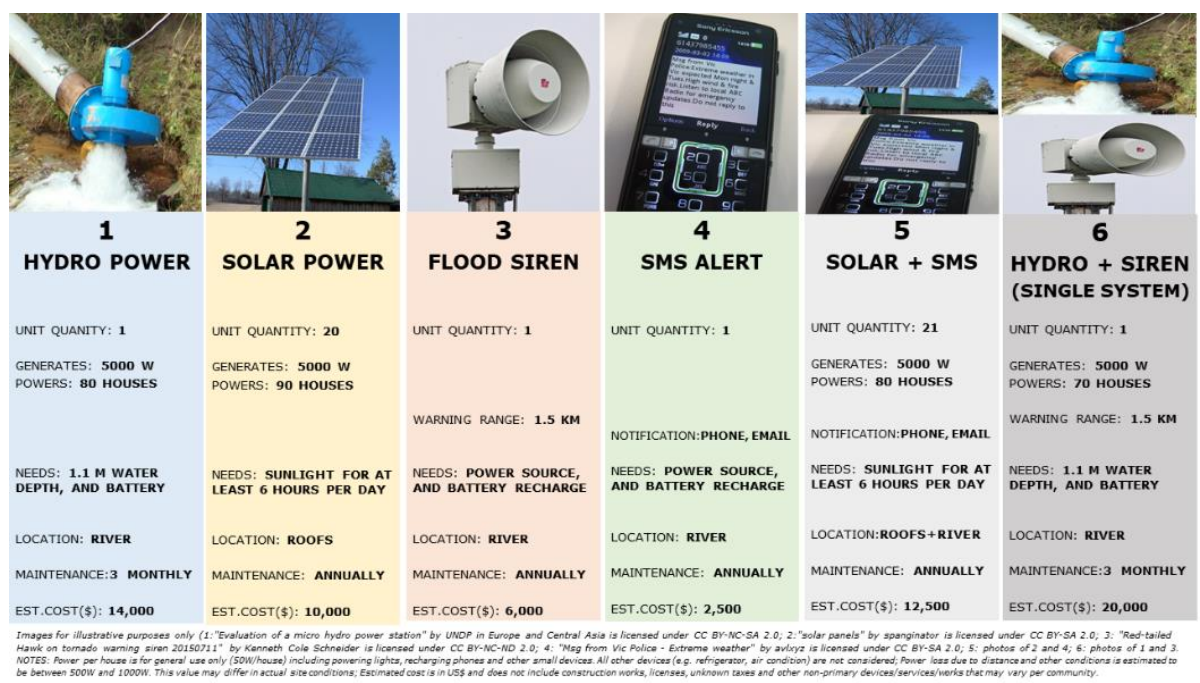

Figure 2. Catalogue of six community assets and their attributes.

Despite the differences in function (i.e., energy generation, flood warning, both) and output, the options were evaluated based on their relative priority and deliverability as assets for the community. The CBCA allows comparisons between options that vary if attributes are common and measurable. For example, Mansuy, Verlinde, and Macharis (2020) [28] compared mobile phones, coffee machines, and washing machines to understand the preference of consumers for "electronic and electrical devices". In this study, participants were asked to choose only one option that best supports their community, based on either single or combined/integrated functions. Their choice helps us understand which community needs (energy, flood warning, or both) should be prioritized for further program development. 


\subsubsection{SCORE Analysis}

This analytical framework supports a detailed evaluation of perceived benefits and potential costs/concerns related to proposed processes or interventions. It readily integrates with the CBCA (Round Two) as it helps understand why participants chose their preferred community asset when assessed against multiple criteria, specifically, which attributes presented strengths, challenges, opportunities, etc., and for what reasons [31].

\subsubsection{Thematic Analysis}

Thematic analysis was used to analyze the data from both rounds of semi-structured interviews using the method described by Braun and Clarke (2014) [32]. This involved familiarization with the data through initial readings of transcripts and analyzing and grouping similar phrases deemed relevant to the research themes into codes. The codes were then grouped together based on similarities and distinctions, which formed the foundation for the sub-themes. The primary coder (first author) and two additional coders participated in the coding process to provide multiple perspectives of the data and act as a validity check [33]. Each coder had a different background discipline (engineering, psychology, journalism), but all were familiar with the development sector. All worked independently following the process described above, then consulted regarding their initial findings resulting in further refinements and creation of the overarching themes.

\subsection{Data Credibility}

Data credibility and validity were ensured using the methods described by Barbour (2001) and Berends and Johnston (2005) [23,34]. We employed heterogeneous sampling, a form of purposive sampling, as the selection of participants with diverse characteristics was required to ensure maximum variability with our primary data [35]. Participants were selected based on specific inclusion criteria (familiarity with local conditions, needs, hazards and energy) and to provide a broad cross-section of end-user perspectives (i.e., community residents and business owners, emergency professionals or academic/technology experts with local knowledge). Verbatim transcription (exact conversion of speech to text) was conducted as it captures all views and emotions of the interviewees. All transcribed data were sent to the interviewees for validation. This allowed the participants to verify and correct, if necessary, their transcribed data before its translation to English. The coding phase included multiple coders to reduce researcher influence and was conducted only with the translated scripts (English) to maintain linguistic consistency [34].

\subsection{Selection of Study Sites}

The selection of the study sites was based on three criteria:

(1) Site appropriateness: As the primary focus of the study related to flood risk and energy insufficiency in riparian settlements, and potential resource development, our focus was on community sites likely to experience such vulnerabilities. Our review of the evidence-based literature [16] identified site characteristics and combinations associated with elevated risk (e.g., high flood risk, remote location, off-grid and/or insufficient/unstable power, lack of flood response planning/infrastructure), and was the basis of site selection in the current study.

(2) Consultation with local partners: Our in-country researchers identified sites that met these criteria in Greece: (a) Aggitis, Drama; (b) Grammeni, Drama; (c) Piges, Drama, and in Nepal: (a) Temal, Kavrepalanchowk; (b) Roshi, Kavrepalanchowk; (c) Dhuskun, Sindhupalchowk.

(3) Participants from identified communities could likely participate in both Round One and Round Two interviews, despite the COVID-19 restrictions in place during the study period. 
Aggitis and Dhuskun were assessed to be the most suitable study sites as they most directly addressed these criteria and were representative of high flood-risk locations within the respective country contexts.

\subsubsection{Aggitis Community and Site}

Aggitis is an on-grid, peri-urban, riparian village, located in the Regional Unit of Drama in Eastern Macedonia and Thrace Administrative Region in northern Greece. The total area of the village is $11.5 \mathrm{~km}^{2}$ and has 82 permanent residents (2011 census) with most aged 65 years or older. The main spoken language is Greek, and its income is principally derived from agriculture, livestock, and ecotourism. Nearby attractions include the Aggitis River, Aggitis Cave (also known as Maaras Cave), and Aggitis Gorge (nearby tourist attractions). The Aggitis Cave is more than $12 \mathrm{~km}$ long, making it the largest cave in Greece and the largest riparian cave in the world.

Aggitis River is the most important tributary of the Strymonas river. It is $75 \mathrm{~km}$ long and sourced in the Falakro massif. The river is formed by the discharge of a $12 \mathrm{~km}$ underground system and passes though the Aggitis Cave [36,37]. Flooding is a common phenomenon in the Aggitis basin, especially during the snow melt period (February to April) or extreme rainfall events. In 2015, a serious flood event in the Aggitis river caused severe damage in the area. This occurred because the local anti-flooding works were insufficient to hold the large amounts of water due to snow-melting. Over 400 farmers were impacted, more than 50,000 hectares were flooded, and some local livestock units were completely vanished [38]. Other serious water-based disasters occurred in June 2014 (hailstorm) and January 2019 (heavy rainfall). With respect to renewable energy sources, local residents are familiar with hydropower and solar power. There is a pico hydropower plant that operates in the area (max. capacity 1.2 MW). The plant does not operate throughout the year (e.g., during summer months). Some residents have installed solar panels in their homes or businesses.

\subsubsection{Dhuskun Community and Site}

Dhuskun (also known as Ghuskun) is an off-grid, rural, riparian village, located in Ward no.3 of Tripurasundari Rural Municipality, Sindhupalchowk District in the Bagmati Province in central Nepal. The total area of the village is $16.12 \mathrm{~km}^{2}$ and has 3116 residents (1991 census). The main languages spoken are Nepali and Newari. Agriculture, animal husbandry, and trade are the main income sources. Dhuskun has potential in the coffee business and ecotourism activities with the Sunkoshi River that flows through the village to be one of the main attractions.

Sunkoshi River is a trans-boundary river that originates from Zhangzangbo Glacier in Tibet and is part of the Koshi River basin in Nepal. The area is very prone to floods and landslides, which occur frequently, particularly during the monsoon season (June to August) or the snow melt period. In 2014 a major landslide occurred in the district and blocked a river creating the artificial lake which is nearby. This caused the surrounded land to erode [39]. Near the village, there is a small hydropower station. Floods and landslides often affect the plant's operations due to its location. Sometimes it remains closed for long periods, leaving Dhuskun and nearby communities with no power. Some government buildings use solar power as backup energy systems.

Figures 3 and 4 show the study site locations maps. Figures 5-8 present scenes from Aggitis and Dhuskun communities. 


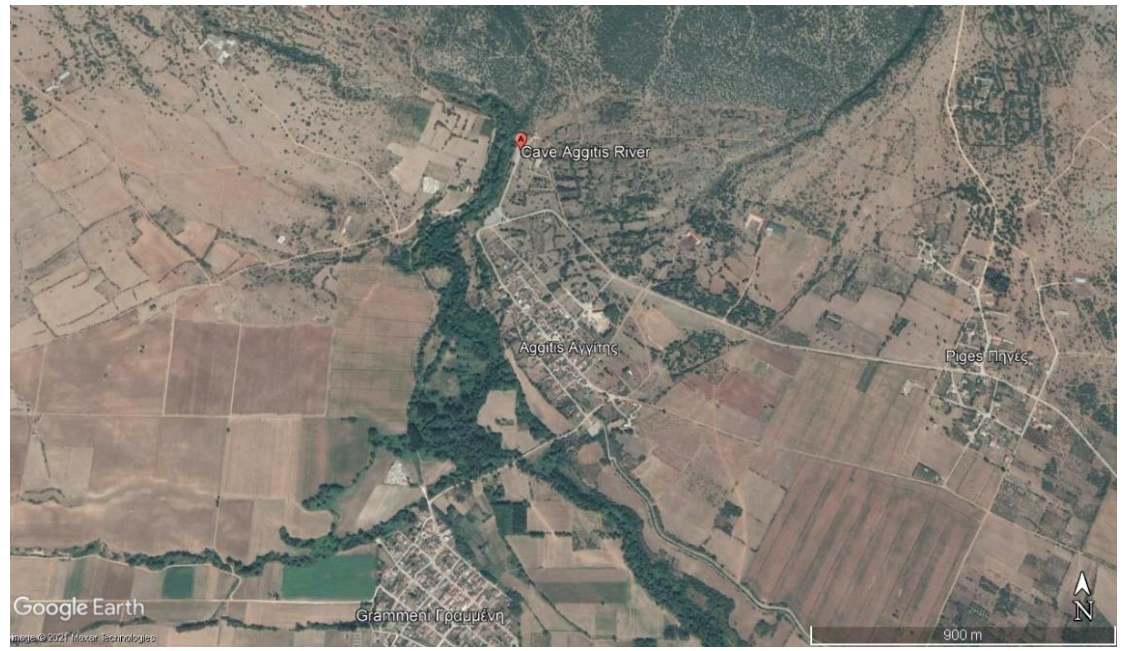

Figure 3. Local study site map of Aggitis, Greece. Source: Google Earth Pro (accessed on: 10 January 2022).

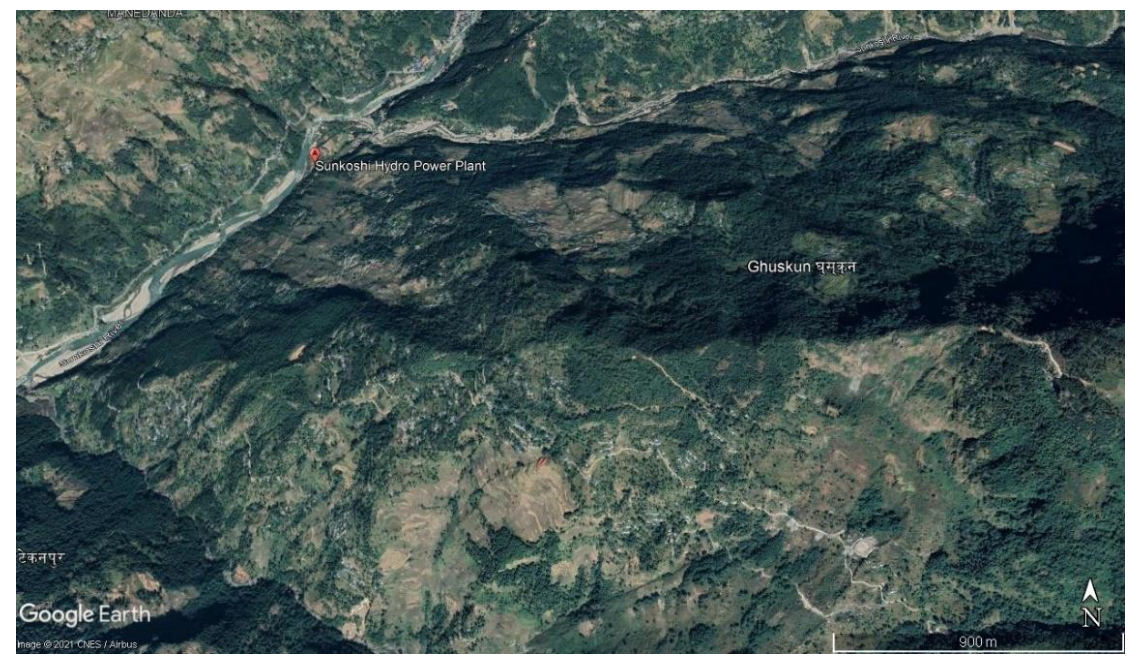

Figure 4. Local study site map of Dhuskun, Nepal. Source: Google Earth Pro (accessed on: 10 January 2022).

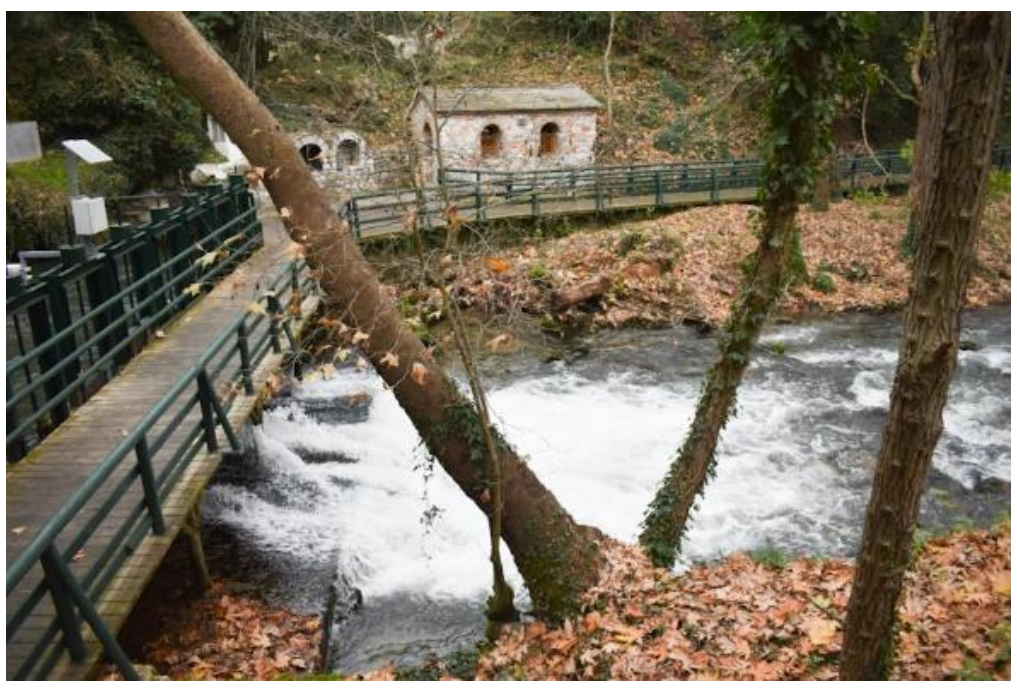

Figure 5. Aggitis River (near Aggitis Cave), Greece. 


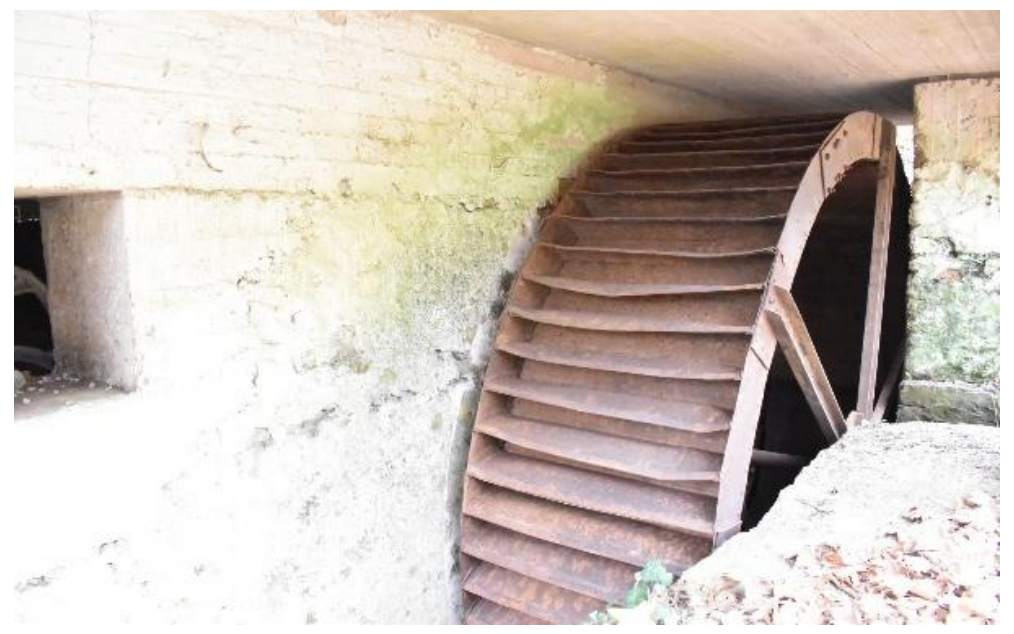

Figure 6. Pico-hydropower system near Aggitis River, Greece.

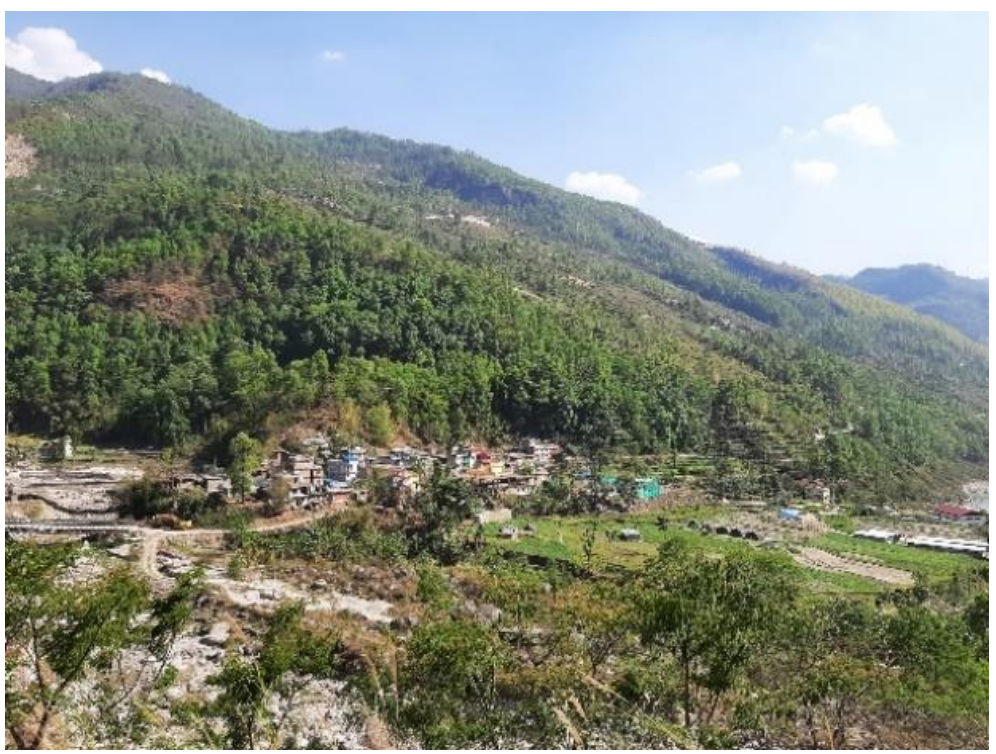

Figure 7. Dhuskun village, Nepal.

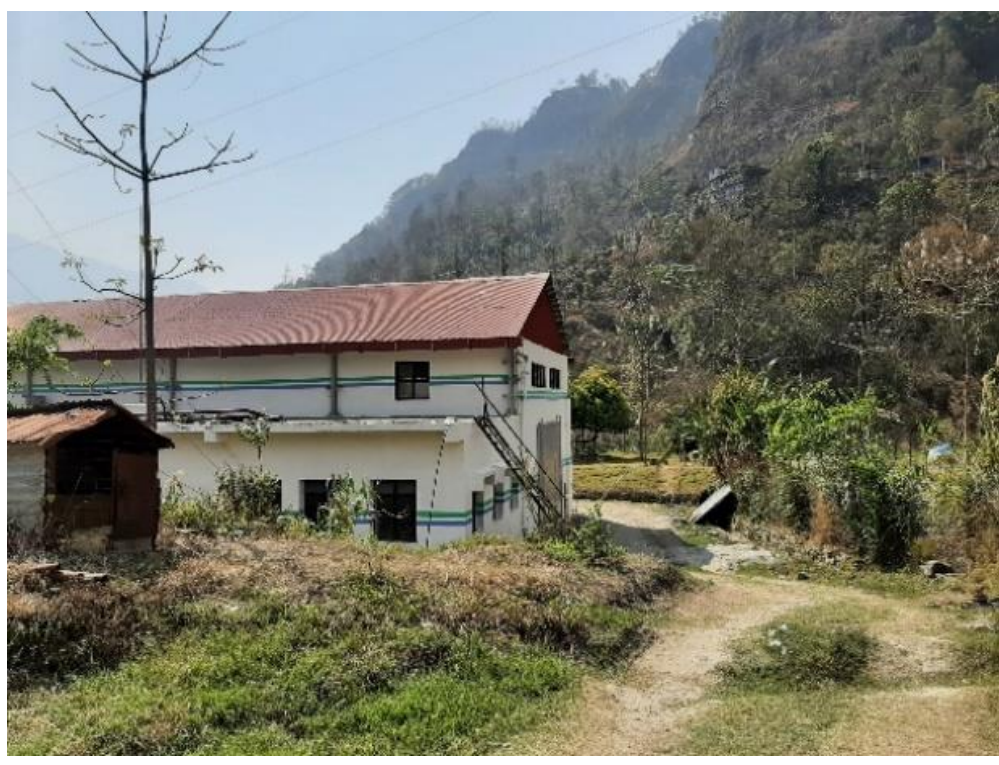

Figure 8. Small hydropower plant near Sunkoshi River, Nepal. 


\subsection{Participant Recruitment and Panel Description}

For this study, local partners in Aggitis (International Hellenic University) and Dhuskun (Kathmandu University) recommended a list of candidates who met the inclusion criteria (knowledge of local conditions, energy sources, hazards, and community needs) and had a potential interest to participate in this research. Three candidates (two from Aggitis and one from Dhuskun) were excluded due to health concerns and unavailability during the time of the interviews. The principal researcher contacted all the remaining participants and used a screening questionnaire to ascertain residency status, familiarity with the local area, energy sources, hazards, and community needs. Based on this screening, all participants were selected for inclusion in this study.

Selected candidates completed a consent form which included identifying and demographic data. These data were gathered to understand the factors affecting different views and concerns. Participants were subsequently de-identified during the data analysis stage and ascribed codes to ensure confidentiality. Purposive sampling was used to ensure a balanced distribution and cross-section of community views, specifically: residents and professionals with local knowledge (i.e., disaster management, academia, technology), gender and age distribution (minimum 18 year), and those with special needs or carer responsibilities (e.g., mobility issues, carers of children or older adults) $[15,17,25]$.

Participants were recruited to form a panel at each site-eight from Aggitis and eight from Dhuskun (16 participants in total). All had basic or higher knowledge of their local site, community energy, and flood resilience needs, renewable energy, and flood early warning concepts. A key requirement of the Delphi method relates to participant familiarity and knowledge with the topic $[40,41]$. As such, panels of this size and representation were considered suitable for the purposes of this exploratory analysis and are consistent with other studies which employ the Delphi method $[19,42]$. The demographic characteristics of the study panels are presented in Table 1.

Table 1. Panel demographic data.

\begin{tabular}{|c|c|c|c|c|}
\hline Role & Age & Gender (M/F/O) & Occupation & $\begin{array}{c}\text { Marital Status } \\
(\mathrm{Y} / \mathrm{N}) \text {-No. of } \\
\text { Children }\end{array}$ \\
\hline \multicolumn{5}{|c|}{ AGGITIS } \\
\hline Academic & 36 & $\mathrm{~F}$ & Academic & $Y-2$ \\
\hline Academic & 40 & $\mathrm{~F}$ & Academic & $\mathrm{N}-0$ \\
\hline $\begin{array}{l}\text { Emergency } \\
\text { Professional }\end{array}$ & 25 & $\mathrm{M}$ & $\begin{array}{c}\text { Emergency Responder/Forest } \\
\text { Warden }\end{array}$ & $\mathrm{N}-0$ \\
\hline Local Resident & 32 & $\mathrm{M}$ & Farm business owner & $Y-1$ \\
\hline Local Resident & 36 & $\mathrm{M}$ & Farm business owner & $Y-2$ \\
\hline Local Resident & 49 & $\mathrm{~F}$ & Homemaker & $Y-0$ \\
\hline Local Resident & 52 & $\mathrm{~F}$ & Local business owner & $Y-3$ \\
\hline Technology Expert & 45 & $\mathrm{~F}$ & $\begin{array}{c}\text { Entrepreneur } \\
\text { (agronomy/flood/irrigation) }\end{array}$ & $Y-2$ \\
\hline \multicolumn{5}{|c|}{ DHUSKUN } \\
\hline Academic & 70 & $\mathrm{M}$ & Academic & $Y-2$ \\
\hline $\begin{array}{l}\text { Emergency } \\
\text { Professional }\end{array}$ & 30 & $\mathrm{M}$ & $\begin{array}{c}\text { Emergency responder/Police } \\
\text { officer }\end{array}$ & $\mathrm{N}-0$ \\
\hline Local Resident & 18 & $\mathrm{M}$ & University student & $\mathrm{N}-0$ \\
\hline Local Resident & 21 & $\mathrm{M}$ & University student & $\mathrm{N}-1$ \\
\hline Local Resident & 30 & $\mathrm{~F}$ & Homemaker & $\mathrm{Y}-3$ \\
\hline Local Resident & 31 & $\mathrm{M}$ & Farm business owner & $\mathrm{Y}-1$ \\
\hline Local Resident & 42 & $\mathrm{~F}$ & Homemaker & $Y-2$ \\
\hline Technology Expert & 31 & M & Hydropower Technician & $\mathrm{Y}-0$ \\
\hline
\end{tabular}




\section{Results}

All panel members in Aggitis (A) and Dhuskun (D) supported a priority transition to renewable energy sources, including hydropower and solar power, arguing that local experience and site conditions could support such technologies (Round One). The majority (A: 5/8; D: 5/8) preferred the hybrid prototype (Option 6) as an appropriate community asset for their community, since it integrated two required services (hydropower generation and flood siren warning) as a stand-alone system and was seen as a more efficient means to deliver these due to the riparian resources that were available. The combination of solar energy panels and flood alert SMS (Option 5) was the second most preferred option (A: 3/8; D: $2 / 8$ ) as it provided free energy from local site conditions (sunlight) and convenience of receiving warning information (via SMS). Asset that offered a single service (i.e., Option 1-small-scale hydropower system was selected by one panel member (D: 1/8) mainly due to its low cost and the available riparian resources (Round Two). Lastly, the remote research approach was viewed positively by all panel members who found that it was convenient and did not restrict their feedback compared to a face-to face interview. The themes that were prominent within the data from each round are presented in the following sections. Table 2 summarizes perceptions of major hazard threats, priority developments for resilience and existing assets (Round One), and preferred assets and related developments (Round Two).

Table 2. Community perceptions of major hazard threats and priority developments.

\begin{tabular}{|c|c|c|c|}
\hline Theme & Sub-theme & Aggitis & Dhuskun \\
\hline & & ROUND ONE & \\
\hline \multirow{5}{*}{ Water hazards } & Natural disasters & $\begin{array}{l}\text { Floods (storms, snow melt): } 8 / 8 \\
\text { COVID-19 pandemic: } 1 / 8\end{array}$ & $\begin{array}{c}\text { Floods (monsoons, snow melt): } 8 / 8 \\
\text { Landslides (usually during floods): } 8 / 8 \\
\text { Earthquakes: } 1 / 8 \\
\text { COVID-19 pandemic: } 1 / 8\end{array}$ \\
\hline & $\begin{array}{l}\text { Flood warning: } \\
\text { (i) current systems }\end{array}$ & $\begin{array}{c}\text { No local warning system: } 8 / 8 \\
\text { Flood SMS alert (not real time-does } \\
\text { not support evacuation, esp. flash } \\
\text { floods): } 2 / 8\end{array}$ & $\begin{array}{c}\text { No local warning system: } 8 / 8 \\
\text { Flood SMS alert (messages delayed and/or } \\
\text { mobile service unavailable-does not assist } \\
\text { response): } 3 / 8 \\
\text { Flood siren at nearby hydropower plant (plant } \\
\text { specific warning, only partial community } \\
\text { coverage): } 1 / 8\end{array}$ \\
\hline & (ii) needs/preferred functions & $\begin{array}{c}\text { Combination (siren and SMS alert): } 5 / 8 \\
\text { Flood siren (wide range, loud): } 2 / 8 \\
\text { Combination (siren, SMS alert, } \\
\text { lights): } 1 / 8 \\
\text { Hydrometric station: } 1 / 8\end{array}$ & $\begin{array}{l}\text { Siren (real time warning, wide range, warns at } \\
\text { night): } 6 / 8 \\
\text { Combination (siren and SMS alert): } 2 / 8\end{array}$ \\
\hline & $\begin{array}{l}\text { Flood evacuation: } \\
\text { (i) training/experience }\end{array}$ & $\begin{array}{l}\text { No training/drills: } 7 / 8 \text {; self-taught } \\
\text { (online): } 1 / 8 \\
\text { No personal evacuation: } 8 / 8\end{array}$ & $\begin{array}{c}\text { No training: } 7 / 8 \text {; participated in evacuation } \\
\text { drills: } 1 / 8 \\
\text { Evacuation due to floods and/or } \\
\text { landslides: } 8 / 8\end{array}$ \\
\hline & $\begin{array}{l}\text { (ii) personal emergency devices - } \\
\text { most used or priority need }\end{array}$ & $\begin{array}{c}\text { Mobile phones (contact others, news } \\
\text { update): } 8 / 8 \\
\text { Lights: } 5 / 8 \\
\text { Oxygen tanks (priority need for older } \\
\text { adults): } 8 / 8\end{array}$ & $\begin{array}{c}\text { Mobile phones (contact others, news } \\
\text { update): } 8 / 8 \\
\text { Lights } 5 / 8 \\
\text { Power banks: } 1 / 8\end{array}$ \\
\hline \multirow{2}{*}{$\begin{array}{l}\text { Community } \\
\text { vulnerabilities }\end{array}$} & Population and infrastructure & $\begin{array}{l}\text { Ageing population (younger adults } \\
\text { move to cities, low-birth rate): } 8 / 8\end{array}$ & $\begin{array}{l}\text { Poor roads, education, drinking water } \\
\text { supply: } 1 / 8\end{array}$ \\
\hline & $\begin{array}{c}\text { Energy supply } \\
\text { (extreme conditions) }\end{array}$ & Unreliable (old infrastructure): $8 / 8$ & $\begin{array}{l}\text { Unreliable (seasonal impacts, unexpected } \\
\text { power outages common): } 8 / 8\end{array}$ \\
\hline $\begin{array}{l}\text { Community } \\
\text { cohesion }\end{array}$ & Help one another & $\begin{array}{l}\text { Support each other (assist older } \\
\text { adults): } 8 / 8\end{array}$ & $\begin{array}{l}\text { Strong bonds between members (small } \\
\text { community is an asset): } 8 / 8\end{array}$ \\
\hline
\end{tabular}


Table 2. Cont.

\begin{tabular}{|c|c|c|c|}
\hline Theme & Sub-theme & Aggitis & Dhuskun \\
\hline \multirow{3}{*}{ Reliable energy } & $\begin{array}{c}\text { Energy supply } \\
\text { (normal conditions) }\end{array}$ & $\begin{array}{c}\text { Reliable-normal conditions (meets daily } \\
\text { needs): } 8 / 8\end{array}$ & Reliable-normal conditions: $6 / 8$ \\
\hline & $\begin{array}{c}\text { Renewable energy (i) existing } \\
\text { assets }\end{array}$ & $\begin{array}{c}\text { Site appropriateness (water and } \\
\text { sunlight): } 8 / 8 \\
\text { Technology acceptance (privately-owned } \\
\text { local hydro and solar): } 8 / 8\end{array}$ & $\begin{array}{c}\text { Site appropriateness (water and sunlight): } 8 / 8 \\
\text { Technology acceptance (hydro for community } \\
\text { use and solar for private/government } \\
\text { use): } 8 / 8\end{array}$ \\
\hline & (ii) asset types needed & $\begin{array}{l}\text { Local hydro (community use): } 8 / 8 \\
\text { Solar (individual use } \\
\text { supported/upscaled): } 7 / 8 \\
\text { Combination (hydro and solar): } 2 / 8 \\
\text { Wind energy: } 2 / 8\end{array}$ & $\begin{array}{l}\text { Small hydro (higher output): } 8 / 8 \\
\text { Solar (community access): } 3 / 8 \\
\text { Combination (hydro and solar): } 2 / 8 \\
\text { Wind energy: } 1 / 8\end{array}$ \\
\hline \multicolumn{4}{|c|}{ ROUND TWO } \\
\hline \multicolumn{2}{|c|}{ Preferred community asset } & $\begin{array}{c}\text { Option } 6 \text { (hydro and siren hybrid): } 5 / 8 \\
\text { Option } 5 \text { (solar and SMS alert } \\
\text { combination): } 3 / 8\end{array}$ & $\begin{array}{c}\text { Option } 6 \text { (hydro and siren hybrid): } 5 / 8 \\
\text { Option } 5 \text { (solar and SMS alert } \\
\text { combination): } 2 / 8 \\
\text { Option } 1 \text { (hydro): } 1 / 8\end{array}$ \\
\hline \multirow[b]{2}{*}{ Multiple services } & Combining proven functions & $\begin{array}{l}\text { Integrated hydro and siren: } 5 / 5 \\
\text { Combined solar and SMS alert: } 3 / 3\end{array}$ & $\begin{array}{l}\text { Integrated hydro and siren: } 5 / 5 \\
\text { Combined solar and SMS alert: } 2 / 3\end{array}$ \\
\hline & Site appropriateness & $\begin{array}{l}\text { Sufficient riparian resources } \\
\text { (water flow): } 2 / 5 \\
\text { Sufficient sunlight throughout } \\
\text { the year: } 2 / 3\end{array}$ & $\begin{array}{l}\text { Sufficient riparian resources (water flow, } \\
\text { depth): } 3 / 5 \& 1 / 1 \\
\text { Sufficient sunlight throughout the year: } 1 / 2\end{array}$ \\
\hline \multirow[b]{2}{*}{$\begin{array}{l}\text { Development } \\
\text { benefits }\end{array}$} & Stakeholder participation & $\begin{array}{l}\text { Collaboration (community stakeholders and } \\
\text { government_funding/management): } 8 / 8\end{array}$ & $\begin{array}{l}\text { Collaboration (community stakeholder, } \\
\text { including public-private partnerships): } 8 / 8\end{array}$ \\
\hline & Economic growth & $\begin{array}{c}\text { Employment opportunities: } 5 / 5 \& 2 / 3 \\
\text { Tourism increase: } 3 / 5 \& 1 / 3 \\
\text { Exemplar community (role model for } \\
\text { other flood-prone communities): } 1 / 5\end{array}$ & Employment opportunities: $4 / 5$ \& 1/1 \\
\hline
\end{tabular}

Aesthetic risks ("ugly"-natural beauty, $\quad$ No risks: $3 / 5,2 / 2$ \& $1 / 1$ traditional buildings): $1 / 5 \& 1 / 3$

Insufficient energy output [install more units]: $4 / 5$

Lack of energy storage [include batteries]: $4 / 5$

Vulnerable in flood conditions [analysis to find optimal hydro locations]: 2/5 River depth limitation - summer [determine best locations]: 2/5

Issues and management (i) technical

Risks and solutions
Insufficient sunlight-cloudy/winter

[large capacity batteries]: $3 / 3$

Siren warning coverage insufficient

[install more units and/or combine with SMS alert]: 3/5

SMS warning unreliable [augment with siren]: $2 / 3$
No funds [funding via stakeholder participation]: $3 / 5 \& 3 / 3$

No human resources for installation and maintenance [works complete via stakeholder participation]: $2 / 5 \& 2 / 3$

Aesthetic risks [community acceptance via

broad stakeholder participation]: 2/5
No major issues: $4 / 5$ \& $2 / 2$

Vulnerable in flood conditions [analysis to find optimal hydro locations]: $2 / 5 \& 1 / 1$

Insufficient sunlight-cloudy/winter [large capacity batteries]: $1 / 2$

Siren warning coverage insufficient [install more units]: $2 / 5$

SMS warning unreliable [augment with siren]: $1 / 2$
Satisfied with remote approach: $8 / 8$ Approach was innovative and comfortable: $1 / 8$

Notes: Fractions in Round One refer to participants from Aggitis (up to 8/8) and Dhuskun (up to 8/8). Fractions in Round Two refer to (a) participants from Aggitis (up to 8/8) and Dhuskun (up to 8/8); (b) participants who selected Option 6-hydro and siren hybrid from Aggitis (up to 5/5) and Dhuskun (up to 5/5); (c) participants who selected Option 5-solar and SMS alert combination from Aggitis (up to 3/3) and Dhuskun (up to 2/2); and (d) a participant who selected Option 1-hydropower generator from Dhuskun (1/1). 


\subsection{Round One}

\subsubsection{Water Hazards}

Participants identified hazard risks affecting their local community and were able to indicate more than one type. The natural disasters of greatest concern were primarily related to flood risks (A: 8/8; D: 8/8) and landslides (D: 8/8), with earthquakes (D: 1/8) and the COVID-19 pandemic (A: 1/8; D: 1/8) reported less often as primary threats. Vulnerabilities related to water hazards included the lack of localized flood warning systems (A: 8/8; D: 8/8) and training/knowledge for evacuation (A: 7/8; D: 7/8). These were considered as priorities in both communities but for different reasons. For Aggitis' participants, insufficient flood warning and lack of flood response planning affected the reliable evacuation of older residents, those with limited mobility, and non-local residents such as tourists (e.g., Aggitis Cave visitors). For Dhuskun, delays in evacuation related to floods and landslides were seen as a particular problem, as these hazards are rapid.

More specifically, all participants said that their community had a high flood exposure risk throughout the year (snow melt period, rainy season, monsoon months in Dhuskun), however, floods were seen more threatening by Dhuskun participants as they could destroy homes and cause casualties. Most panel members from both communities said that despite the high flood risk potential, they did not receive any training for flood evacuation. The Aggitis panel members explained that they did not have to evacuate their homes due to extreme past flood events. This was because most residencies were located a safe distance from the river. However, when floods occurred, they said that there was damage to businesses (e.g., restaurants near the river) and tourism (when Aggitis Cave is flooded, it remains closed to visitors for weeks or months). One Aggitis participant said that they once helped an older farmer to evacuate their flooded farm. Dhuskun panel members who were asked a similar question said that they had to evacuate their house at least once due to floods and/or landslides. This was done either with the support of emergency professionals or other community members. This situation was common in Dhuskun, and any delays could result in lethal outcomes.

(Male, 30-Dhuskun): "... I worked in a rescue (team) after a landslide where about twenty to twenty-five people died."

A serious flood-related vulnerability for both communities was the lack of flood warning systems at the local level. All panel members stated that their community had no localized flood early warning systems.

(Female, 49-Aggitis): "Nothing! We have absolutely nothing (no early warning systems)!"

Some participants said that they sometimes received flood SMS alerts by the Civil Protection Services, but these were unreliable, received slow, or lost due to poor mobile services during extremes. Notably, one Dhuskun participant said that the nearby hydropower plant had a flood warning siren installed to alert workers, but it did not offer direct support to the community-only partial community coverage.

All participants considered the need for a localized, reliable flood early warning systems as a high priority. Expressed preferences for a warning mode were stand-alone sirens (A: 2/8; D: 6/8), combined flood sirens and flood alert SMS/email services (A: 5/8; D: 2/8), combined flood sirens, emergency lights and flood alert SMS/email services (A: 1/8). One Aggitis panel member also suggested the use of a hydrometric station (a device placed near a water body that collects and records water quantity and quality data) as a more comprehensive solution. For Aggitis, combined warning systems (the most preferred choice) would warn both older adults (limited use of mobile phones) and younger adults (more frequent access to phones and laptops). For Dhuskun, outdoor sirens (most preferred choice) would be more efficient since SMS services were not reliable when the weather was bad. As they explained, sirens could provide real-time warning, cover a wide range, and be more useful when people were sleeping. Similar benefits were also discussed by the Aggitis participants who chose sirens as their main system (stand-alone systems or in combination with other types). 
In a flood scenario with long power outage, all panel members found mobile phones to be an essential emergency device, mainly for communication and receiving information, with lights (as a function on the phone or a sole device) to be also essential (A: 5/8; D: 5/8). Oxygen tanks were also considered as important emergency devices for Aggitis participants (A: $8 / 8$ ) due to the large population of older adults in the village.

When asked about the COVID-19 crisis and its significance compared to the flood disasters, only two-panel members (A: 1/8; D: 1/8) described it as a high priority threat, explaining that this is a pandemic (prevalent to the whole world) and everyone is stressed about it at present. The remaining panel members said that the pandemic did not pose a serious threat to their community (it could be controlled), unlike the floods that occurred at any time and without much warning. It should be noted that the interviews took place in April, May, and July 2021 when lockdowns and other restrictions were forced in most countries around the world, including Greece and Nepal.

\subsubsection{Community Vulnerabilities}

More broadly for Aggitis, a community vulnerability of greatest concern included ageing population (A: 8/8), with some participants highlighting the low-birth rate in their community, the decision of many younger adults to move to bigger cities, and the lack of opportunities for young business owners in the area, despite its ecotourism potential.

(Male, 36-Aggitis): "[ . . ] the community is made up mostly of people over the age of sixty-five ... seventy ... who are retired or nearing retirement age. The younger generation chooses not to live in Aggitis, but in a bigger city and to have a house there, so to live both in Aggitis and in the big city, like I do. Therefore, the community is shrinking."

During extreme weather events, all panel members found their community's energy supply unreliable and were dissatisfied with the energy status. The main reasons included the condition of technical equipment and systems which were old or poorly maintained, the severe impacts of seasonal conditions (floods, thunderstorms, etc.) in the system, and unexpected power outages (due to technical or other reasons). For Aggitis, continuous power generation was vital because, as they explained some older adults needed oxygen support and any power disruption could cause problems to their health. Both communities said that the power outages could last for hours, however, two Dhuskun participants pointed out that if the water hazards were serious, they would damage the nearby hydropower plant and cause damages that would take months to fix. In addition, for Dhuskun, power outages during extremes could also affect the work of emergency responders (e.g., no power in local police station).

One Dhuskun participant said that besides these vulnerabilities, their community also needed better transportation, education, and water supply infrastructure.

\subsubsection{Community Cohesion}

All participants highlighted community cohesion as a critical community capacity and the fact that community members still cared for one another. In the scenario where the early warning was insufficient or could not be reached by some sensitive groups (e.g., people with hearing or visibility impairments), all panel members said that other people in their community (family members or neighbors) who lived nearby would notify and assist them. While this seems like an obvious response, some panel members pointed out the fact that their community still cared for their members and would not leave anyone "behind", particularly during flood evacuation.

(Male, 70-Dhuskun): "In Nepal, and in Sunkoshi (Dhuskun) community, people tie up in such a way that if one knows about it, they will warn other people. One thing. And second thing is, who is living in which house, because everyone knows everyone's name. That is what I noticed. So, if and when time permits, time permits, those who can hear, they will ask other people and inform them." 


\subsubsection{Reliable Energy}

Other community capacities included energy reliability under normal conditions (A: 8/8; D: 6/8), and the renewable energy potential in the local site (A: 8/8; D: 8/8). With respect to the energy, all Aggitis panel members stated that the usual supply satisfied their daily needs. The majority of Dhuskun panel members stated the same. Those who disagreed highlighted the scheduled power outages, which sometimes affected businesses.

Notably, all panel members nominated renewable energy types as their preferred energy source due to environmental and socio-economic benefits, "clean" power generation, and low cost. For example, both communities stated that small-scale hydropower systems (A: 8/8; D: 8/8), solar panels (A: 7/8; D:3/8), and their combination (A: 2/8; D: 2/8) would be ideal for their area since their village was by the river, there was sufficient sunlight, and hydropower and solar panel infrastructures already existed in the area. It should be noted that some participants (A: 2/8; D: 1/8) also suggested the use of small wind turbines but were unsure if this was a realistic option.

\subsection{Round Two}

In Round Two, we presented a catalogue of six community assets (Figure 2). Most panel members selected Option 6-hydropower, flood siren hybrid prototype (A: 5/8; D: 5/8), followed by Option 5-combination of solar energy panels and flood alert SMS (A: 3/8; D: 2/8), followed by Option 1—stand-alone hydropower generator (D: 1/8).

\subsubsection{Multiple Services}

The most attractive attributes for Option 6 were its feature to provide combined hydropower generation and siren warning in a hybrid manner (two services under one stand-alone system) and its site appropriateness (river flow). For Option 5, the features of solar power and flood alert SMS services were the most attractive attributes, followed by the convenience of receiving flood alerts on personal electronic devices. It can be observed that the majority of participants $(15 / 16)$ chose an option that provides multiple services, but with the combination of hydropower and siren warning preferred by twice as many participants (10:5), due to the perceived reliability and feasibility of their respective services as presented in Round One.

The panel member who selected Option 1 found it the most realistic option for Dhuskun, given its low cost and site conditions (river flow). When asked about their preference regarding a combination of systems (Option 5) or a hybrid system (Option 6), they stated that the hybrid has more advantages and seems to be a more feasible solution for their community.

(Male, 70-Dhuskun): "Generally, you know, hybrid system is the most better way to do it. [ ... ] of course, solar might be necessary, but it will be nominal only so when damage occurs (due to floods), when maintenance might be necessary. At that time, solar can help it, because of batteries and all. But when we install the batteries and all, the batteries will have a life, so once that life will be completed, then another set will be necessary, which is very difficult because it costs money again. And also disposing the batteries is very difficult. In that case, you know, first thing is I prefer to have hydro (Option 1), and second is hybrid system (Option 6)."

\subsubsection{Development Benefits}

All panel members found economic benefits after the installation of their preferred community assets, including employment and new business potential. All panel members pointed out the synergy between community groups, academics, local authorities, and others as a crucial requirement for the successful funding, installation, operation, and maintenance of their preferred community asset.

(Female, 45-Aggitis): "A combination of these people (professional and non-professional stakeholders who are familiar with the community) and organizations could be involved 
in order to study the area, install the system and manage the project. They can be found in the wider area, within the competent bodies (authorities and organizations). Initially, the competent municipality in collaboration with the local district (authorities) could do research regarding the financing of this program, or set up an auction so the project can be completed by private companies. That is, I think the ideal would be for all the (competent) bodies to work together, because I do not think that the municipality alone has the know-how to do such a thing."

\subsubsection{Risks and Solutions}

Most panel members envisaged no significant risks for their communities after the installation of their selected community assets (A: 6/8; D: 6/8). For the remaining Aggitis panel members, risks of low concern included aesthetic risks that could affect the tourist traffic if the community asset was "ugly" and did not blend with the local natural scape (both Options 5 and 6). For the remaining Dhuskun panel members, the risks focused on the protection of the system against natural hazards and potential damage in the riparian ecosystem-e.g., alternations in local biodiversity (Option 6).

Participants raised a number of issues of technical and resource nature. Specifically for Aggitis, the greatest challenges were the limited energy output, lack of batteries, and high cost. Participants who raised these issues said that these could be solved by installing more units, including batteries to store power for later use, and involving multiple stakeholders in the project to secure sufficient funding. These issues were not raised by any Dhuskun participants. Additionally, for Option 6, panel members from both communities worried that the unit could be damaged during floods (and landslides for Dhuskun). The need for site analysis in both communities for the selection of appropriate locations for system installation was suggested as a solution. This issue and solution were also raised by the panel member who selected Option 1. Another common concern for both Options 5 and 6 was the need to upgrade the suggested early warning features, so to improve coverage and reliability by either installing more units or combining different warning types (i.e., siren and SMS alert).

(Female, 36-Aggitis): "There are now sirens that can be combined with safety lights [ . . .

]. Sirens that could be combined with sending a text message or an email, which would not be difficult to do [..]. Whenever someone who might be away from the sirens (out of range) or, for example, someone who sleeps with earplugs, probably would not be able to hear the siren but maybe they could see the notification alert, if their mobile phone was vibrating."

For Option 5, both communities discussed the insufficient sunlight during some winter months or cloudy days. The use of larger capacity batteries was suggested as a potential solution. Some Aggitis participants who chose Option 6 mentioned a similar issue as there could be a river depth limitation in some locations; the appropriate investigation of optimal locations was nominated as a solution. Lastly, some Aggitis panel members said that their community may not have the resources to manage such installations over time and that their presence could negatively affect tourist traffic. One counter view was that a well-developed project could attract tourists as a sustainability demonstration project. To solve these concerns, participants recommended the engagement of multiple stakeholders.

\subsection{Remote Research Participation}

All panel members (A: 8/8; D: 8/8) approved the study's remote research approach. They found it convenient and safe to participate, given the distance and COVID-19 restrictions. They understood all the provided materials and had easy access to the research activities, despite some minor technical/internet issues.

\section{Discussion}

According to the World Risk Index 2019 (https: / / reliefweb.int/ sites / reliefweb.int/ files/resources/WorldRiskReport-2019_Online_english.pdf accessed on: 30 November 2021), Greece's exposure to natural hazards is very high, compared to Nepal's, which is 
low, however, its coping and adaptive capacities levels are higher than Nepal's. This comparison provides a cogent example of why high-income countries are often more resilient to natural hazards. It does not rest simply with the hazard frequency and severity, but also the available resources and infrastructure invested for disaster resilience [1]. However, when it comes to floods, high-income countries are not always well-prepared, particularly at the local level. Recent record-breaking floods in Germany (https: / www.theguardian.com/ world/2021/jul/19/german-villages-could-be-left-with-no-drinking-water-after-floods accessed on: 4 December 2021) and the United States (https:/ /www.nytimes.com/2021/09/ 03/nyregion/nyc-ida.html accessed on: 4 December 2021) show that early warning systems were not adequate at the local level, including urban areas, and could not detect the precise severity and location of the flash floods that occurred because they were designed to operate for larger scales. Conversely, there is some evidence that simpler and "low-tech" flood early warning systems that have strong community participation in low-income communities, such as in the Hindu Kush Himalaya region (https:/ /www.icimod.org/mountain/cbfews/ accessed on: 1 December 2021) are very effective and could find applications in more "developed" areas [43]. Another factor that could support flood resilience is the use of off-grid renewable energy systems. This energy type can run independently and is rarely interrupted during weather extremes [8,9], hence, it should be highly considered in all phases of flood risk management.

Aggitis and Dhuskun face a range of natural hazards and vulnerabilities, with water disasters being a high priority. Hazard frequency (floods occur almost every year), previous losses, and a lack of community preparedness were cited as major reasons why this hazard type was seen as more threatening than others (e.g., earthquakes). For Dhuskun, landslides were of equally high concern, also due to the loss of life and damage caused in past events. In contrast, it is notable that the COVID-19 pandemic was not cited as a major threat or priority management issue in either community. Participants at both sites saw this as a shorter-term issue, national and global in nature, and importantly, it could be controlled through vaccination, and compliance with stay-at-home orders, masks, etc. As such, it was seen as qualitatively different from other natural hazards such as floods. Another possible explanation is that COVID-19 impacts are more visible in urban areas with high population density and not in smaller communities like Aggitis and Dhuskun [44].

Our initial needs assessment (Round One) found that all panel members preferred a complete transition to renewable energy sources, particularly hydropower and solar power. This would increase the communities' energy autonomy, reduce current energy costs and create job opportunities. While most Aggitis participants mentioned both hydropower and solar systems, the majority of Dhuskun participants chose hydropower as their preferred main energy source. This was possibly because Dhuskun was already receiving energy from the local hydropower plant and people were more familiar with this technology, unlike Aggitis residents who primarily received power from the main grid.

Notably, both communities lacked flood early warning mechanisms and there was an expressed need to develop such a capability, particularly flood sirens and SMS alerts. For Aggitis, combining these was seen as an ideal option because they would potentially reach different groups; older adults who lived alone (siren) and younger people (SMS text). Dhuskun participants preferred sirens as they were seen as more reliable (e.g., unaffected by telecommunications issues during storms) and could have wide, localized coverage. These findings are consistent with other literature showing that community-based early warning systems in rural areas generally employ flood siren systems rather than SMS services [16]. This is because rural areas often have poor network services, and sirens are a more efficient and cost-effective means of warning.

Panel members also highlighted a lack of flood education and training (e.g., evacuation drills). This is significant, as lack of procedural knowledge (what to do, when) can increase stress and impair decision-making during emergencies, and may contribute to increased fatalities [45]. Participants pointed out a related factor regarding the importance of continuous power supply, particularly during floods and other emergencies. Participants in Aggitis 
raised particular concerns for older residents, some of whom had mobility issues, specific health needs (e.g., supplemental oxygen) and lived on their own. Collectively, the findings suggest a constellation of factors likely to result in poor flood emergency flood response in both riparian communities: lack of localized early warning with rapid inundation, vulnerable subgroups (older adults, tourists, non-residents), hazard-related power loss, and lack of flood education and practiced procedures. The absence of flood warning capabilities for both groups is a critical element of this risk profile as this response infrastructure often provides the enabling platform that supports coordinated community preparedness. That is, if sirens/SMS alerts become the "when" (to act), communities can then begin to tackle the "how" in a more coordinated way (e.g., evacuation drills, rally points/signage/shelters, neighbor checks/counts, etc.) [46]. However, as participants also stated, these response systems are critically dependent on uninterrupted power. As such, while participants on both sites endorsed a transition to renewable energy (favoring hydropower and solar power) for daily energy and environmental reasons, power reliability in emergency situations was also a "front of mind" concern usually based on their lived experiences.

Community members noted key capabilities and strengths that could support renewable energy and hazard preparedness projects. These drew on common "foundation" attributes (e.g., sufficient sunlight, river flow), but also key differences across sites-e.g., the Sunkoshi River (Dhuskun) depth remained above $1.1 \mathrm{~m}$ throughout the year, but in Aggitis, it dropped below this depth in some locations, especially during summer. Under normal conditions, most panel members reported that the existing energy supply and infrastructure were sufficient for the local communities. In addition, all Aggitis participants said that continuous energy supply was important for the older adults who lived alone and needed medical support. While family unity and connection are strong in both Greek and Nepali cultures, older Greek adults prefer living alone, so they don't become a "burden" to other family members [47]. In Nepali families, older adults usually live with their children [48]. This cultural difference in living arrangements likely accounts for the greater concerns for older residents expressed by all the Aggitis panel members, including the need for continuous power during extreme weather events.

For Dhuskun, power interruptions could affect local businesses, but when these occurred during weather extremes, they had the potential to disrupt emergency operations and potentially contribute to the loss of lives. For such reasons, both communities saw a priority need for continuous, locally managed power, and this is perhaps why they supported the development of new, off-grid renewable energy systems. Such systems could work independently, either as main power sources or supplementary systems, and do so when the main power system is disrupted or offline.

Another interesting finding was that both community panel members believed that local residents would help those at risk, such as older adults, people with disabilities, and others. This is consistent with Winterton and Warburton (2012) [49], who concluded that small communities in rural areas are more "homogenous" and care for one another compared to urban populations.

In Round Two, most panelists selected the hybrid system (Option 6) as the most suitable community asset, due to its low environmental risk potential, use of nearby river resources for power generation, flood siren function, and economic benefits. Option 5 was the second most preferred choice for similar reasons. In part, this reflected a largely common view across the two sites on key issues, notably: preferred energy source, warning optimization, system protection in extreme conditions, and funding strategies). The differences cross-site tended to reflect socio-cultural and environmental perspectives. For example, some Aggitis participants expressed concerns that such an installation would be seen as "ugly" and could affect tourism, while one participant stated that a well-developed project could attract more people and highlight Aggitis' focus on sustainability. Aesthetic risks were not mentioned by Dhuskun panel members, possibly because Dhuskun is less dependent on tourism and hydropower infrastructure is already situated on their river. Other differences related to geomorphology. Dhuskun panel members emphasized land- 
slide risks in their area and were concerned that the intervention would not survive such an event. Aggitis respondents pointed out that the system may not work if it is installed in areas where the river depth can become shallow. These differences highlight that technical interventions are rarely a one-size-fits-all solution and must be tailored, through consultations, to address specific local conditions and needs.

Lastly, our data collection approach, which was largely conducted via videoconference interviews, was reported to be an acceptable method by all panel members. Participants indicated that it did not restrict their access or reporting in any way and offered advantages in terms of convenience and time savings. In fact, several indicated that they preferred it to other approaches. As such, remote research could be considered in other humanitarian engineering research where physical engagement is not feasible or where the travel and logistics costs of a study may be prohibitive.

The following section focuses on the hybrid unit development (Option 6) as the most preferred community asset and presents the next steps for prototype development.

\subsection{Research Translation: Developing a Hybrid Prototype}

The study findings indicated that there was a strong preference for the hybrid unit that combines hydropower generation and flood early warning. In order to reach longerterm sustainability and wide community acceptance, the development of such prototypes should follow the best strategies used in similar community-based interventions. While the literature presents very limited information on such hybrid systems, information about stand-alone successful or failed renewable energy and early warning case studies could inform this pilot program $[15,16]$. Table A1 (Appendix A) is informed by the appropriate technology and systems evaluation tool, which frames a checklist of dimensions of system sustainability [16]. This tool is considered in our study for the development of the hybrid prototype, and it presents concerns and suggestions made by the panel members. For all phases of the prototype development, we will follow the SIMILAR Process, which is an appropriate method for industrial engineering and prototype production, and encompasses well with a comprehensive systems approach for hydropower generation and flood resilience $[15,50]$. Lastly, to allow the continuous mapping of the energy and flood response alternations in Aggitis and Dhuskun, the use of vulnerability and capability mapping is suggested [13]. This tool considers internationally known/accepted metrics for both pre and post-hazard conditions and allows cross-community comparisons.

\subsection{Limitations and Future Work}

While the principal researcher could conduct interviews with Greek participants directly, it is possible that intercultural awareness may have affected the interview process with Nepali participants. To support intercultural sensitivity, these interviews were jointly conducted with an on-site Nepali researcher, and the interview process was reviewed with Nepali research colleagues to ensure awareness and insights regarding cultural perceptions informed the dataset. The decision to primarily focus on themes related to energy reliability and flood-related risks, limited review of other community hazards and concerns mentioned by some participants (e.g., earthquakes, low-birth rate) that may warrant program support. Similarly, this study examined culturally and infrastructure distinct peri-urban and rural communities, and, therefore, generalizing its findings to other rural, peri-urban, or urban communities would require caution. Our ongoing research will engage a wider range of such riparian communities to strengthen the reliability of its findings and confirm key similarities and differences in flood-prone settlements. Using the information from this initial exploratory study, analyses with more participants, including in-situ studies and co-development of prototype models and other community assets, could be supported.

\section{Conclusions}

Riparian communities exposed to water disasters and energy insufficiency need humanitarian engineering support and services. Renewable energy and flood warning sys- 
tems can provide much-needed assets for such communities, but their success is grounded in sustained collaboration between local and professional stakeholders. In this paper, we present a research design that allows effective engagement of a range of such stakeholders and across a range of contexts. Our findings indicate that participants from Aggitis, Greece and Dhuskun, Nepal preferred options with multiple services compared to well-established but monofunctional systems, and that the combination of hydropower and siren offered the most attractive option, endorsed by twice as many participants as the next preferred combination (solar and SMS). Integrating these services into a single unit was seen to offer efficiency gains while also supporting greater community input and control as a co-developed asset. A prototype with such features will be piloted in the next stage of this research and has the potential to promote sustainable development and flood resilience within our partner communities.

Supplementary Materials: The following supporting information can be downloaded at: https:/ /www. mdpi.com/article/10.3390/geosciences12020071/s1, Table S1: Interview Questions Round One conducted during April-May 2021, Table S2: Interview Questions Round Two conducted during July 2021.

Author Contributions: Conceptualization, S.S. (Spyros Schismenos), G.J.S., N.G., D.E., S.S. (Surendra Shrestha) and B.S.T.; methodology, S.S.(Spyros Schismenos), G.J.S., and N.G.; validation, S.S.(Spyros Schismenos), S.G., and G.J.S.; investigation, S.S.(Spyros Schismenos), S.S. (Surendra Shrestha), D.E., and B.S.T.; writing—original draft preparation, S.S. (Spyros Schismenos); writing-review and editing, S.S.(Spyros Schismenos), G.J.S., N.G., D.E., S.S. (Surendra Shrestha), B.S.T., and S.G; visualization, S.S.(Spyros Schismenos); supervision, G.J.S., N.G., D.E., S.S. (Surendra Shrestha), and B.S.T. All authors have read and agreed to the published version of the manuscript.

Funding: This research was funded by the School of Social Sciences, Western Sydney University.

Data Availability Statement: No new data were created or analyzed in this study. Data sharing is not applicable to this article.

Acknowledgments: This study was approved by the Western Sydney University Human Research Ethics Committee (HREC Approval Number: H14269). The authors would like to thank Mr Sushobhan Bhattarai, School of Engineering, Kathmandu University, for assisting the team with data collection and analysis.

Conflicts of Interest: The authors declare no conflict of interest.

\section{Appendix A}

Table A1. Checklist for prototype development and sustainability.

\begin{tabular}{ccc}
\hline $\begin{array}{c}\text { Dimensions of System } \\
\text { Sustainability }\end{array}$ & Panel Concerns/Suggestions & $\begin{array}{c}\text { Prototype Features/Services } \\
\text { (What Will Be Considered) }\end{array}$ \\
\hline $\begin{array}{c}\text { Autonomy (Community } \\
\text { Self-Sufficiency) }\end{array}$ & $\begin{array}{c}\text { Reliable flood early warning, 24/7 } \\
\text { power generation }\end{array}$ & $\begin{array}{c}\text { Real-time flood warning, daily and emergency } \\
\text { energy }\end{array}$ \\
\hline $\begin{array}{c}\text { Co-Creation (Local and } \\
\text { Professional Stakeholders) }\end{array}$ & $\begin{array}{c}\text { Interest in system's development, } \\
\text { operation, and maintenance }\end{array}$ & Multiple stakeholder participation in the program \\
\hline $\begin{array}{c}\text { Community Input } \\
\text { (Engagement) }\end{array}$ & $\begin{array}{c}\text { Interest in system's development, } \\
\text { operation, and maintenance }\end{array}$ & Multiple stakeholder participation in the program \\
\hline $\begin{array}{c}\text { Community Controlled } \\
\text { (Managed, Owned) }\end{array}$ & $\begin{array}{c}\text { Community controlled or co-managed } \\
\text { with other stakeholders }\end{array}$ & $\begin{array}{c}\text { Aiming for the unit to be community } \\
\text { managed/owned or co-managed/co-owned }\end{array}$ \\
\hline $\begin{array}{c}\text { Legal and Regulatory } \\
\text { Support (Technical, }\end{array}$ & $\begin{array}{c}\text { Public, or private, or joint project } \\
\text { To be considered at a later stage with local } \\
\text { communities and governments }\end{array}$ \\
\hline Administrative, Financing)
\end{tabular}


Table A1. Cont.

\begin{tabular}{|c|c|c|c|}
\hline & $\begin{array}{l}\text { Dimensions of System } \\
\text { Sustainability }\end{array}$ & Panel Concerns/Suggestions & $\begin{array}{l}\text { Prototype Features/Services } \\
\text { (What Will Be Considered) }\end{array}$ \\
\hline \multirow{7}{*}{ 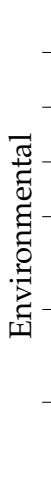 } & Habitat Neutral & Not to affect the local ecosystem & Aiming for low/no environmental risks \\
\hline & Low Emergy & Not to affect the local ecosystem & Aiming for low / no environmental risks \\
\hline & Low Emissions & Need for zero emissions & Unit is a renewable energy system (no emissions) \\
\hline & Renewable Energy & Need for renewable energy transition & Unit supports hydropower generation \\
\hline & $\begin{array}{l}\text { Renewable Resources } \\
\text { Availability }\end{array}$ & $\begin{array}{l}\text { Local site resources can support } \\
\text { system's operations }\end{array}$ & Riparian site conditions will be considered \\
\hline & $\begin{array}{c}\text { Scaled for Conditions } \\
\text { (Resources, Weather, Land) }\end{array}$ & $\begin{array}{l}\text { Must fit in local site characteristics (e.g., } \\
\text { river water depth) }\end{array}$ & Unit will be modified so to be site appropriate \\
\hline & $\begin{array}{l}\text { Waste Utilization and } \\
\text { Reduction }\end{array}$ & $\begin{array}{l}\text { Local site resources can support } \\
\text { system's development }\end{array}$ & $\begin{array}{l}\text { Parts of the unit could be made by local waste } \\
\text { materials (e.g., plastic) }\end{array}$ \\
\hline \multirow{8}{*}{ 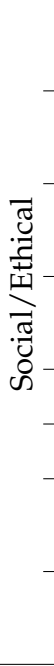 } & Acceptability & $\begin{array}{l}\text { Aggitis and Dhuskun possibly willing } \\
\text { to participate in this program }\end{array}$ & $\begin{array}{l}\text { Inform both communities of research study and } \\
\text { seek acceptance }\end{array}$ \\
\hline & Aesthetics & $\begin{array}{l}\text { Not to affect tourism-it should } \\
\text { increase visitors' traffic }\end{array}$ & $\begin{array}{l}\text { System's design will be co-decided with } \\
\text { professional and local stakeholders }\end{array}$ \\
\hline & Ease of Use & $\begin{array}{l}\text { Older adults and people with } \\
\text { disabilities should be considered }\end{array}$ & Aiming for the unit to be user-friendly \\
\hline & $\begin{array}{c}\text { Gender Appropriate (e.g., } \\
\text { women in staff/management) }\end{array}$ & $\begin{array}{l}\text { Engagement of different community } \\
\text { groups, including women }\end{array}$ & Priority in all project phases \\
\hline & Indigenous Techniques & Local knowledge to be considered & Priority in all project phases \\
\hline & Knowledge, Skills, Feedback & Local knowledge to be considered & Priority in all project phases \\
\hline & Social Entrepreneurialism & $\begin{array}{l}\text { Need for youth employment, } \\
\text { environmental sustainability }\end{array}$ & $\begin{array}{l}\text { Unit will be designed based on socio-cultural and } \\
\text { environmental justice criteria }\end{array}$ \\
\hline & $\begin{array}{l}\text { Socio-Cultural, incl. health, } \\
\text { education, harmony, etc. }\end{array}$ & $\begin{array}{l}\text { Need for community resilience, } \\
\text { development, and well-being }\end{array}$ & $\begin{array}{l}\text { Aiming to support community capabilities under } \\
\text { this project }\end{array}$ \\
\hline \multirow{7}{*}{ 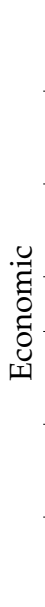 } & Affordability & $\begin{array}{l}\text { Lack of local funds and human } \\
\text { resources }\end{array}$ & $\begin{array}{l}\text { Seek support from multiple stakeholders, } \\
\text { sponsors, local/national/international funds }\end{array}$ \\
\hline & Income Generating & $\begin{array}{c}\text { Need for new (and youth) employment } \\
\text { opportunities }\end{array}$ & $\begin{array}{l}\text { Aiming to support community capabilities under } \\
\text { this project }\end{array}$ \\
\hline & Job Creating & $\begin{array}{l}\text { Need for new (and youth) employment } \\
\text { opportunities }\end{array}$ & $\begin{array}{l}\text { Aiming to support community capabilities under } \\
\text { this project }\end{array}$ \\
\hline & Money Saving & Low installation and maintenance costs & Priority in all project phases \\
\hline & Labor Intensive & $\begin{array}{l}\text { Lack of human resources/aging } \\
\text { population }\end{array}$ & $\begin{array}{l}\text { System will be autonomous/semi-autonomous } \\
\text { (low labor-intensive) }\end{array}$ \\
\hline & Resource Efficiency & $\begin{array}{l}\text { Community has capacity/resources to } \\
\text { support this initiative }\end{array}$ & Priority in all project phases \\
\hline & Selling Appropriate & $\begin{array}{l}\text { Community could become a role model } \\
\text { to other communities }\end{array}$ & Aiming to promote Aggitis and Dhuskun \\
\hline \multirow{4}{*}{ 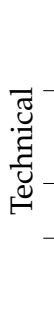 } & Adaptability & $\begin{array}{l}\text { Adjust to different conditions (e.g., } \\
\text { seasonal) }\end{array}$ & $\begin{array}{l}\text { Unit will be adaptable based on different site } \\
\text { conditions }\end{array}$ \\
\hline & $\begin{array}{l}\text { Constructability and } \\
\text { Replicability }\end{array}$ & $\begin{array}{l}\text { Unit to be easily constructible and } \\
\text { replicable }\end{array}$ & $\begin{array}{c}\text { Aiming to make the unit DIY (do-it-yourself) and } \\
\text { EDO (easy-to-deploy-and-operate) }\end{array}$ \\
\hline & Compatibility & - & Will be considered during the development phase \\
\hline & $\begin{array}{l}\text { Durability (e.g., against time } \\
\text { or extremes) }\end{array}$ & $\begin{array}{l}\text { Unit not to be damaged/washed away } \\
\text { by floods and landslides }\end{array}$ & Will be considered during the development phase \\
\hline
\end{tabular}


Table A1. Cont.

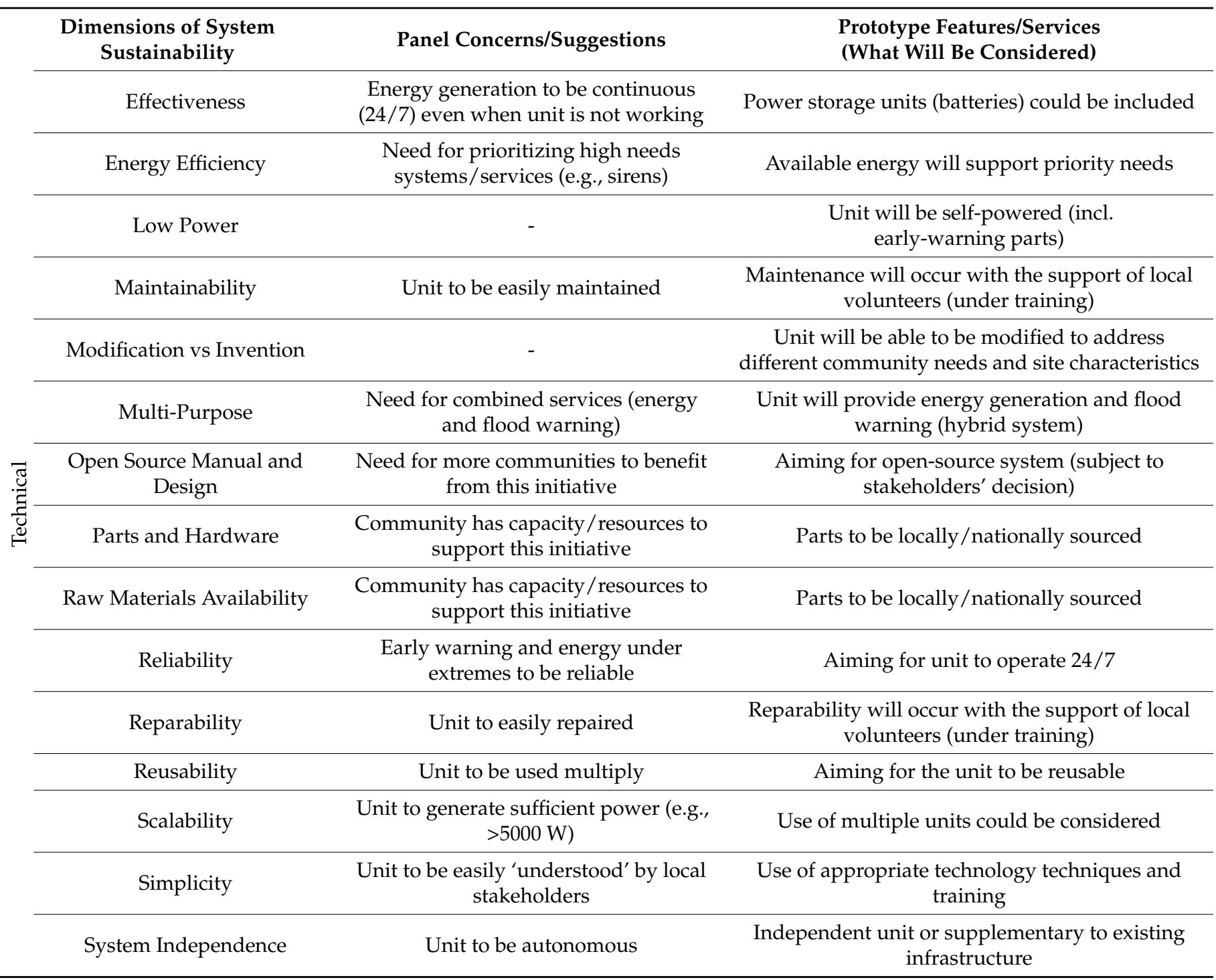

\section{References}

1. Strömberg, D. Natural disasters, economic development, and humanitarian aid. J. Econ. Perspect. 2007, 21, 199-222. [CrossRef]

2. Flooding Triggers Landslides in Nepal and India, Killing at Least 150 People and Washing Away Homes. Available online: https:/ / www.abc.net.au/news/2021-10-22/india-nepal-deadly-floods/100558832 (accessed on 30 October 2021).

3. Greece's Wildfires May Be Dying Down on the Island of Evia, but White-Hot Anger Rises in Its Place. Available online: https: //www.abc.net.au/news/2021-08-15/greece-wildfires-devour-the-island-of-evia/100368262 (accessed on 30 October 2021).

4. Silverstein, K. The Energy Crisis Is Spreading Faster than the Coronavirus and COP26 Leaders Face a Faustian Choice. Available online: https: / www.forbes.com/sites/kensilverstein/2021/10/13/the-energy-crisis-is-spreading-faster-than-the-coronavirusand-cop26-leaders-face-a-faustian-choice/ ?sh=56e7cbe168a7 (accessed on 30 October 2021).

5. Schismenos, S.; Stevens, G.J.; Emmanouloudis, D.; Georgeou, N.; Shrestha, S.; Chalaris, M. Humanitarian engineering and vulnerable communities: Hydropower applications in localised flood response and sustainable development. Int. J. Sustain. Energy 2020, 39, 941-950. [CrossRef]

6. Death Toll Passes 180 in Nepal and India Floods. Available online: https://www.bbc.com/news/world-asia-india-58951456 (accessed on 29 October 2021).

7. Lighting Up Africa: Bringing Renewable, Off-Grid Energy to Communities. Available online: https://www.worldbank.org/en/ news/feature/2020/08/13/lighting-up-africa-bringing-renewable-off-grid-energy-to-communities (accessed on 29 January 2022).

8. D'Cunha, S.D. How Off-Grid Renewable Energy Came to the Rescue in India's Flood Zones. Available online: https: //www.forbes.com/sites/suparnadutt/2017/09/15/how-off-grid-renewable-energy-came-to-the-rescue-in-indias-floodzones $/$ ?sh=6df386fabc49 (accessed on 27 January 2022). 
9. Phillips, C. Combining Energy Efficiency and Disaster Mitigation Efforts in Residential Properties. Available online: https: / / www.huduser.gov/portal/periodicals / em/spring17/highlight2.html (accessed on 27 January 2022).

10. Cariolet, J.-M.; Vuillet, M.; Colombert, M.; Diab, Y. Building resilient and sustainable: A need to decompartementalise the researches. E3S Web Conf. 2016, 7, 13012. [CrossRef]

11. Mazzurco, A.; Jesiek, B.K. Five Guiding Principles to Enhance Community Participation in Humanitarian Engineering Projects. J. Humanit. Eng. 2017, 5. [CrossRef]

12. Hill, S.; Miles, E. What do Students understand by the term 'Humanitarian Engineering'. In Innovation, Practice and Research in Engineering Education; Coventry University: Coventry, UK, 2012; pp. 1-11.

13. Schismenos, S.; Stevens, G.J.; Emmanouloudis, D.; Georgeou, N.; Shrestha, S.; Chalaris, M. Humanitarian engineering at the sustainability-development nexus: Mapping vulnerability and capability factors for communities at risk of water-based disasters. Sustain. Sci. 2021, 16, 1185-1199. [CrossRef]

14. Skokan, C.; Munoz, D. Humanitarian Engineering Program-Challenges in the Execution of Remote Projects. Available online: https: / / citeseerx.ist.psu.edu/viewdoc/download?doi=10.1.1.522.2478\&rep=rep1\&type=pdf (accessed on 27 January 2022).

15. Schismenos, S.; Stevens, G.J.; Emmanouloudis, D.; Georgeou, N.; Shrestha, S.; Katopodes, N.D. Using off-grid hydropower for community-led flood resilience: An integrated systems approach. Int. J. Sustain. Energy 2021, 1-15. [CrossRef]

16. Schismenos, S.; Stevens, G.; Emmanouloudis, D.; Georgeou, N.; Shrestha, S.; Katopodes, N.; Wali, N. Humanitarian engineering for renewable energy and flood early warning in remote communities: A scoping review of enabling factors and sustainability. $J$. Sustain. Dev. Energy Water Environ. Syst. 2021, in press. [CrossRef]

17. Schismenos, S.; Stevens, G.J.; Georgeou, N.; Emmanouloudis, D.; Shrestha, S.; Thapa, B.S. Humanitarian and Developmental Research Engagement during COVID-19. Soc. Sci. Protoc. 2021, 4, 1-14. [CrossRef]

18. de Brito, M.M.; Evers, M.; Höllermann, B. Prioritization of flood vulnerability, coping capacity and exposure indicators through the Delphi technique: A case study in Taquari-Antas basin, Brazil. Int. J. Disaster Risk Reduct. 2017, 24, 119-128. [CrossRef]

19. Skulmoski, G.J.; Hartman, F.T.; Krahn, J. The Delphi method for graduate research. J. Inf. Technol. Educ. Res. 2007, 6, 1-21. [CrossRef]

20. Helmer, O. Analysis of the Future: The Delphi Method; Rand Corp.: Santa Monica, CA, USA, 1967.

21. Asjes, K. The Hidden Benefits of Remote Research. Available online: https://www.uxbooth.com/articles/hidden-benefitsremote-research/ (accessed on 27 January 2022).

22. Barriball, K.L.; While, A. Collecting data using a semi-structured interview: A discussion paper. J. Adv. Nurs.-Inst. Subscr. 1994, 19, 328-335. [CrossRef] [PubMed]

23. Barbour, R.S. Checklists for improving rigour in qualitative research: A case of the tail wagging the dog? BMJ 2001, 322, 1115-1117. [CrossRef]

24. Collingridge, D. Validating a Questionnaire. Available online: https://www.methodspace.com/blog/validating-a-questionnaire (accessed on 22 September 2021).

25. Georgeou, N.; Hawksley, C. Enhancing Research Impact in International Development: A Practical Guide for Practitioners and Researchers. Research for Development Impact Network: Deakin, Australia, 2020.

26. Lebeau, K.; Van Mierlo, J.; Lebeau, P.; Mairesse, O.; Macharis, C. A choice-based conjoint analysis on the market potential of PHEVs and BEVs in Flanders. World Electr. Veh. J. 2012, 5, 871-880. [CrossRef]

27. Lee, H.-J.; Huh, S.-Y.; Yoo, S.-H. Social preferences for small-scale solar photovoltaic power plants in South Korea: A choice experiment study. Sustainability 2018, 10, 3589. [CrossRef]

28. Mansuy, J.; Verlinde, S.; Macharis, C. Understanding preferences for EEE collection services: A choice-based conjoint analysis. Resour. Conserv. Recycl. 2020, 161, 104899. [CrossRef]

29. Tanujaya, R.R.; Lee, C.-Y.; Woo, J.; Huh, S.-Y.; Lee, M.-K. Quantifying public preferences for community-based renewable energy projects in South Korea. Energies 2020, 13, 2384. [CrossRef]

30. Ebers, A.; Wüstenhagen, R.; Tabi, A.; Kostyuchenko, N.; Smolennikov, D.; Joller, L. Local Acceptance of Wind Energy in Switzerland, Estonia and Ukraine. A Cross-Country Analysis based on Choice Experiments. University of St. Gallen: Gallen, Germany, 2017.

31. Njoh, A.J.; Etta, S.; Ngyah-Etchutambe, I.B.; Enomah, L.E.; Tabrey, H.T.; Essia, U. Opportunities and challenges to rural renewable energy projects in Africa: Lessons from the Esaghem Village, Cameroon solar electrification project. Renew. Energy 2019, 131, 1013-1021. [CrossRef]

32. Braun, V.; Clarke, V. What Can "Thematic Analysis" Offer Health and Wellbeing Researchers? Int. J. Qual. Stud. Health Well-Being 2014, 9, 26152. [CrossRef]

33. Fereday, J.; Muir-Cochrane, E. Demonstrating rigor using thematic analysis: A hybrid approach of inductive and deductive coding and theme development. Int. J. Qual. Methods 2006, 5, 80-92. [CrossRef]

34. Berends, L.; Johnston, J. Using multiple coders to enhance qualitative analysis: The case of interviews with consumers of drug treatment. Addict. Res. Theory 2005, 13, 373-381. [CrossRef]

35. Black, K. Business Statistics: For Contemporary Decision Making; John Wiley \& Sons: Hoboken, NJ, USA, 2019.

36. Novel, J.-P.; Dimadi, A.; Zervopoulou, A.; Bakalowicz, M. The Aggitis karst system, Eastern Macedonia, Greece: Hydrologic functioning and development of the karst structure. J. Hydrol. 2007, 334, 477-492. [CrossRef] 
37. Pennos, C.; Lauritzen, S.; Pechlivanidou, S.; Sotiriadis, Y. Geomorphic constrains on the evolution of the Aggitis River Basin Northern Greece (a preliminary report). Bull. Geol. Soc. Greece 2016, 50, 365-373. [CrossRef]

38. Serres Farmers in Despair from the Disasters Caused by Strymonas. Available online: https://www.kathimerini.gr/society/8096 65/se-apognosi-oi-agrotes-stis-serres-apo-tis-katastrofes-poy-prokalei-o-strymonas / (accessed on 22 September 2021).

39. Manandhar, R. After Lake Burst, Dhuskun Folk Fear More Landslips, Floods. Available online: https://kathmandupost.com/ national/2014/09/11/after-lake-burst-dhuskun-folk-fear-more-landslips-floods (accessed on 19 September 2021).

40. Grisham, T. The Delphi technique: A method for testing complex and multifaceted topics. Int. J. Manag. Proj. Bus. 2009, 2, 112-130. [CrossRef]

41. Mullen, P.M. Delphi: Myths and reality. J. Health Organ. Manag. 2003, 17, 37-52. [CrossRef]

42. Ogbeifun, E.; Agwa-Ejon, J.; Mbohwa, C.; Pretorius, J. The Delphi technique: A credible research methodology. In Proceedings of the International Conference on Industrial Engineering and Operations Management, Kuala Lumpur, Malaysia, 8-10 March 2016; pp. $8-10$.

43. UNFCCC. Community-Based Flood Early-Warning System / India. Available online: https://unfccc.int/climate-action/ momentum-for-change/activity-database/community-based-flood-early-warning-system-india (accessed on 10 January 2022).

44. Kang, Y.; Baidya, A.; Aaron, A.; Wang, J.; Chan, C.; Wetzler, E. Differences in the early impact of COVID-19 on food security and livelihoods in rural and urban areas in the Asia Pacific Region. Glob. Food Secur. 2021, 31, 100580. [CrossRef]

45. Fahy, R.F.; Proulx, G. Toward creating a database on delay times to start evacuation and walking speeds for use in evacuation modeling. In Proceedings of the 2nd International Symposium on Human Behaviour in Fire, Boston, MA, USA, 26-28 March 2001; pp. 175-183.

46. Dufty, N.; Taylor, M.; Stevens, G. Why are people so unkind? Unravelling community responses to floodplain and emergency management. In Proceedings of the 52nd Floodplain Management Association Conference, Batemans Bay, NSW, Australia, 17-20 May 2012.

47. Panagiotopoulos, G.; Walker, R.; Luszcz, M. A comparison of widowhood and well-being among older Greek and BritishAustralian migrant women. J. Aging Stud. 2013, 27, 519-528. [CrossRef]

48. Egan, R.; Bowes, S. Community Support for Seniors: A Case Study of the Newly Emerging Bhutanese Community; Western Sydney University: Sydney, Australia, 2013.

49. Winterton, R.; Warburton, J. Ageing in the bush: The role of rural places in maintaining identity for long term rural residents and retirement migrants in north-east Victoria, Australia. J. Rural. Stud. 2012, 28, 329-337. [CrossRef]

50. Bahill, A.T.; Gissing, B. Re-evaluating systems engineering concepts using systems thinking. IEEE Trans. Syst. Man Cybern. Part C 1998, 28, 516-527. [CrossRef] 